\title{
Decreased T Cell Levels in Critically III Coronavirus Patients: Single-Center, Prospective and Observational Study
}

This article was published in the following Dove Press journal: Journal of Inflammation Research

\author{
Jingjing $X u^{\prime}$ \\ Zhiyu Liu ${ }^{2}$ \\ Haitao Liu' \\ Yunpeng Luo $^{3}$ \\ Kai Kang ${ }^{3}$ \\ Xueting $\mathrm{Li}^{\prime}$ \\ Wei Yang ${ }^{3}$ \\ Dongsheng $\mathrm{Fei}^{3}$ \\ Changsong Wang (D) ${ }^{1,3}$ \\ Kaijiang $\mathrm{Yu}^{3}$ \\ 'Department of Critical Care Medicine, \\ Harbin Medical University Cancer \\ Hospital, Harbin, Heilongjiang Province, \\ People's Republic of China; ${ }^{2}$ Department \\ of Laboratory Diagnostics, First Affiliated \\ Hospital of Harbin Medical University, \\ Harbin, Heilongjiang Province, People's \\ Republic of China; ${ }^{3}$ Department of \\ Critical Care Medicine, The First \\ Affiliated Hospital of Harbin Medical \\ University, Harbin, Heilongjiang Province, \\ People's Republic of China
}

Background: Since Dec. 2019, the COVID-19 pandemic has been an outbreak. T cells play an important role in dealing with various disease-causing pathogens. However, the role of T cells played in COVID-19 patients is still unknown. Our study aimed to describe the immunologic state of the critically ill COVID-19 patients.

Methods: A total of 63 patients with confirmed COVID-19 pneumonia were admitted to the Department of Intensive Care Unit of the First Affiliated Hospital of Harbin Medical University. The immunologic characteristics (lymphocyte apoptosis, the expression of PD1 and HLA-DR in $\mathrm{T}$ cells, $\mathrm{T}$ cell subset levels, redistribution and the production of inflammatory factors) as well as their laboratory parameters were compared between severe group and critical group.

Results: The level of T cells in peripheral blood was decreased in critical patients compared with that in severe patients, but the expression levels of PD-1 (CD4 ${ }^{+}: 24.71 \%$ VS $30.56 \%$; $\mathrm{CD}^{+}: 33.05 \%$ VS $32.38 \%$ ) and HLA-DR (T cells: $36.28 \%$ VS $27.44 \%$; monocytes: $20.58 \%$ VS $23.83 \%$ ) in T cells were not significantly changed, and apoptosis and necrosis were not different in lymphocytes (apoptosis: $1.04 \%$ VS 1.27\%; necrosis: 0.67\% VS 1.11\%), granulocytes, or monocytes between those two groups.

Conclusion: There is severe immunosuppression in critically ill COVID-19 patients. Redistribution of $\mathrm{T}$ cells might be the main reason for lymphocytic decline. Decreasing the infiltration of $\mathrm{T}$ lymphocytes in the lung may be beneficial for the treatment of COVID-19. Keywords: COVID-19, T lymphocytes, PD-1, HLA-DR, redistribution

\section{Introduction}

Since Dec. 2019, an outbreak of pneumonia cases caused by severe acute respiratory syndrome coronavirus 2 (SARS-CoV-2) began in Wuhan, ${ }^{1,2}$ however, up to date, there is no conclusion about the origin of the SARS-CoV-2. As of Feb. 16. 2021, the number of confirmed pneumonia cases reached 110 million, and the cumulative number of deaths was 2429818. A recent report demonstrated that SARS-CoV-2 infection leads to ICU admission and high mortality. ${ }^{3}$ However, there are few studies on the immunologic function of COVID-19 patients.

T cells play an important role in dealing with various disease-causing pathogens. It differentiates into several subsets of effector cells, including $\mathrm{T}$ helper type I (Th1), Th2, Th17, T follicular helper (Tfh), and regulatory $\mathrm{T}$ (Treg) cells. ${ }^{4}$ Treg cells inhibit autoimmune responses. Cytokines are the determinant factors for $\mathrm{T}$ cell differentiation. For example, the proinflammatory cytokine IL-6, produced by
Correspondence: Changsong Wang Department of Critical Care Medicine, Harbin Medical University Cancer People's Republic of China Email changsongwangicu@।63.com

Kaijiang Yu

Department of Critical Care Medicine, The First Affiliated Hospital of Harbin Medical University, No. 23 Youzheng Street, Harbin, Heilongjiang Province, People's Republic of China Email drkaijiang@I63.com
Journal of Inflammation Research 2021:14 1331-1340 
macrophages and $\mathrm{T}$ cells, is a critical determinant factor for driving Th17 cell differentiation and inhibiting Treg cell differentiation. ${ }^{5-7}$ In recent studies, $T$ cell level reduction was confirmed in COVID-19 patients. ${ }^{8,9}$ This finding may indicate the presence of immunosuppression in patients with COVID-19. However, the reason for the reduction is still not clear. In our study, we explored the mechanism of immunosuppression in these patients. The immune status of COVID-19 patients will be described by lymphocyte apoptosis, the expression of PD-1 and HLADR in T cells, T cell subset levels and the production of inflammatory factors. Our findings will help us understand the immunologic mechanism of COVID-19.

\section{Patients and Methods}

The study was approved by the Ethics Committee of the First Affiliated Hospital of Harbin Medical University. Written informed consent was regularly obtained from all patients upon admission to the Department of Intensive Care Medicine, the First Affiliated Hospital of Harbin Medical University (the intensive care center for severe COVID-19 patients in Harbin, Heilongjiang Province). The 63 confirmed COVID-19 patients in the intensive care unit (ICU) were severe/critical according to the Guidelines of the Diagnosis and Treatment of New Coronavirus Pneumonia (version 6) published by the National Health Commission of China or to the Sequential Organ Failure Assessment (SOFA) score. All the patients enrolled in this retrospective singlecenter study were admitted to the ICU from Feb. 12th to Mar. 26th, 2020.

Severe COVID-19 patients were defined as those satisfying any of the following criteria: 1. Patients who had hypoxemia at rest; hypoxemia was defined as arterial oxygen tension $\left(\mathrm{PaO}_{2}\right)$ over inspiratory oxygen fraction $\left(\mathrm{FIO}_{2}\right)$ of less than $300 \mathrm{mmHg}$ or arterial oxygen saturation of $93 \%$ or lower. 2. Patients whose breathing rates were greater than 30 breaths per minute.

Critical patients were defined as COVID-19 patients who required high-flow nasal cannula or higher-level oxygen support measures to correct hypoxemia.

All medical record information, including epidemiological, demographic, clinical manifestation, and laboratory data were obtained. All data were checked by a team of trained physicians.

\section{Laboratory Examination}

Laboratory confirmation of COVID-19 was performed by the local CDC according to the Chinese CDC protocol.
Throat swab specimens were collected from all patients, and the samples were maintained in viral transport medium for laboratory testing. Specimens, including sputum and blood, were cultured to identify pathogenic bacteria or fungi that may be associated with COVID-19 infection. A lymphocyte test kit (Beckman Coulter Inc., FL, USA) was used for lymphocyte subset analysis. The concentrations of serum cytokines (IL-2, IL-4, IL-6, IL-10, TNF- $\alpha$, and IFN- $\gamma$ ) were quantitatively determined by a Human Th1/Th2 Cytokine Kit (Saiji Biotec, Hangzhou, China) as described in the instruction manual.

The expression of PD-1 was analyzed using a $\mathrm{BD}$ FACSCalibur (BD Biosciences, CA, USA) flow cytometer. Peripheral blood cells were surface stained with mouse anti-human CD8-FITC (BD Biosciences, CA, USA), CD4PE (BD Biosciences, CA, USA) and CD279 (PD-1)-APC (Biolegend, CA, USA) monoclonal antibodies for $15 \mathrm{~min}-$ utes in the dark at room temperature. After lysing with $1 \mathrm{X}$ BD FACS Lysing Solution (BD Biosciences, CA, USA), cells were then washed two times with PBS. Data were analyzed using Kaluza software (Version 2.1)(Beckman Coulter, IN, USA). The following monoclonal antibody panel was used for surface staining: CD8-FITC (BD Biosciences, CA, USA), CD4-PE (BD Biosciences, CA, USA) and CD279 (PD-1)-APC (Biolegend, CA, USA) for PD-1 expression on lymphocytes; CD14-FITC (BD Biosciences, CA, USA) and HLA-DR-PerCP (Miltenyi, Bergisch Gladbach, Germany) for HLA-DR expression on monocytes; CD4-FITC (Quanto Bio, Beijing, China), CD25-PE (Quanto Bio, Beijing, China) and CD127-APC (Quanto Bio, Beijing, China) for Treg cells. The stained samples were further lysed, washed, and resuspended in $200 \mu \mathrm{L}$ of PBS before acquisition.

Apoptosis was determined by a FITC Annexin V Apoptosis Detection Kit I (BD Biosciences, CA, USA) after lysing samples with a lysing solution that did not contain a fixative agent. Then, the cells were washed and stained with Annexin V-FITC and PI as described in the instruction manual.

Acquisitions of samples were carried on FACSCalibur flow cytometer (BD Biosciences, CA, USA). Cytokines data were analyzed using FCAP Array ${ }^{\mathrm{TM}}$ software (Version 3.0) (BD Biosciences, CA, USA), other data were analyzed using Kaluza software (Version 2.1)(Beckman Coulter, IN, USA).

Figure 1 shows the patient flowchart in this prospective and observational study. 


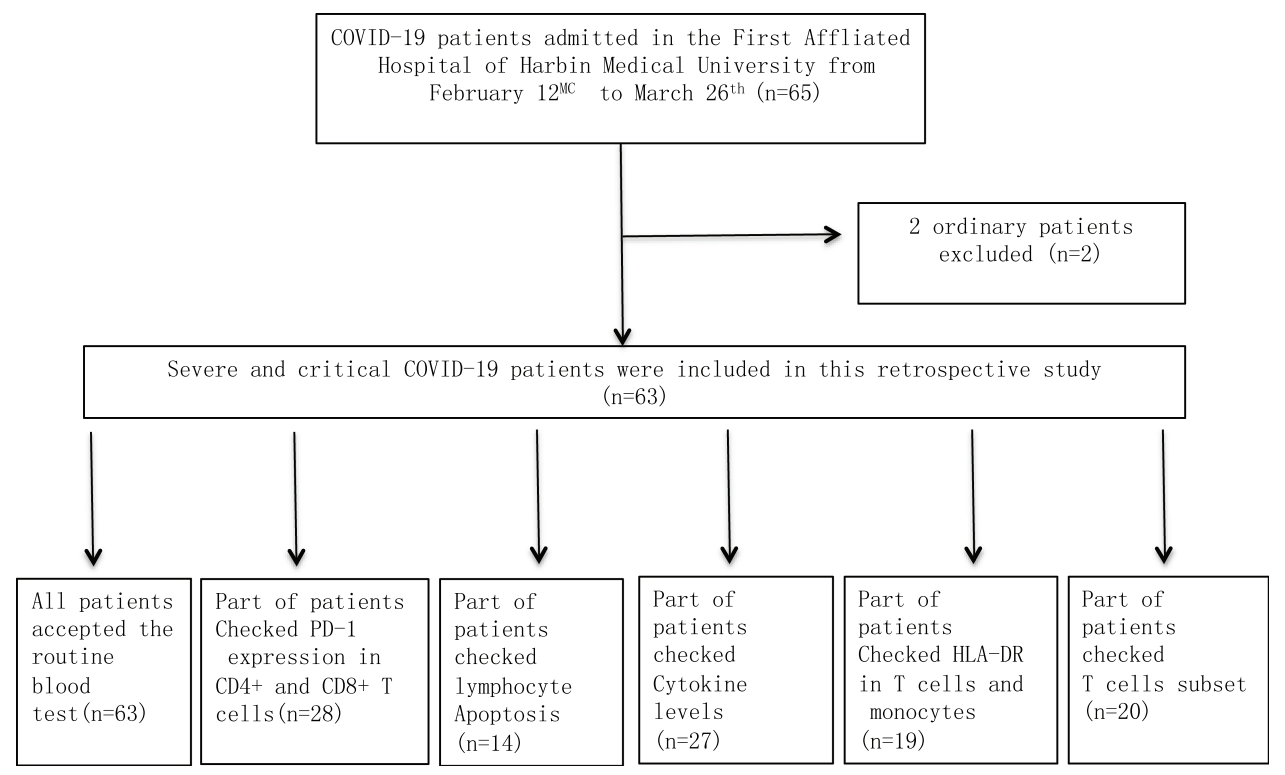

Figure I Flowchart of COVID-19 patients.

\section{Statistical Analyses}

The quantized variables of parameters are expressed as the mean \pm standard deviation, and the significance was tested by $t$-test. Nonparametric variables are expressed as median and quartile intervals [M (P25, P75)], and significance was tested by Wilcoxon rank-sum test. $P<0.05$ was considered statistically significant in all statistical analyses. The Spearman rank correlation coefficient was used to analyze correlations. All statistical analyses were performed by Statistical Analysis System (SAS) (version 9.1.3, SAS Institute Inc., Cary, NC, USA).

\section{Results}

\section{Patient Information}

As of Mar. 26th, 2020, a total of 63 hospital-admitted patients with pneumonia were diagnosed with laboratory-confirmed COVID-19 in Harbin Medical University First Affiliated Hospital and were enrolled in our study. Those patients were divided into two groups: patients with $\mathrm{SpO}_{2} 93 \%$, respiratory rate 30 per min, or oxygenation index $(\mathrm{OI})<300$ as the severe group $(n=27)$, whereas patients with the abovementioned signs and needed mechanical ventilation or had organ dysfunction complications as the critical group $(\mathrm{n}=36)$. The characteristics of these patients are described, we found that the difference in SOFA scores was statistically significant $(\mathrm{p}=0.031)$. The routine blood tests on the 63 COVID-19 patients showed that white blood cell (WBC) and neutrophil counts were normal in the severe group $(5.31 \times 10 / \mathrm{L}$ and $72.1 \%)$ but were slightly increased in the critical group $(7.86 \times 10 / \mathrm{L}$ and $84 \%)$. However, lymphocyte counts were significantly lower in the critical group and decreased by almost $60 \%$ compared with those in the severe group (Table 1). According to these findings, we hypothesized that there was a relationship between the SOFA score and indicators from routine blood tests. To investigate this relationship, we performed linear correlation analysis between these indicators and the SOFA score.

\section{The Level of T Cells in Peripheral Blood Was Decreased in Critically III Patients}

Our findings showed that the SOFA score was negatively correlated with lymphocyte counts, WBC counts, and neutrophil counts, especially lymphocyte counts $(\mathrm{P}<0.0001)$ (Table 2 ). This result indicated that lymphocyte counts and lymphocyte ratio were negatively correlated with disease severity in COVID-19 patients; furthermore, lymphocytic decline was an important marker for the outcome of this disease. Then, we tried to explore the reason for lymphocytic decline. We hypothesized that apoptosis was the main reason for lymphocytic decline. To investigate this hypothesis, we tested the apoptosis of $\mathrm{CD}^{+} \mathrm{T}$ lymphocytes in peripheral blood.

\section{The Expression of PD-I in CD4+ T Cells Was Increased but Not Significantly Altered}

The immune-inhibitory factor PD-1 can activate the apoptosis signaling pathway and induce the apoptosis of 
Table I Baseline Characteristics of COVID-I9 Patients

\begin{tabular}{|c|c|c|c|c|}
\hline Variables & Total $(n=63)$ & Severe Patients $(n=27)$ & Critical Patients $(n=36)$ & $P$ value \\
\hline Age (years) & $65.33 \pm 12.28$ & $67.15 \pm 12.29$ & $63.97 \pm 12.27$ & 0.314 \\
\hline Gender & & & & 0.716 \\
\hline Female & $32(50.79)$ & $13(48.15)$ & $19(52.78)$ & \\
\hline Male & $31(49.21)$ & $14(55 \mid .85)$ & $17(47.22)$ & \\
\hline White blood cell count $\left(\times 10^{9} / \mathrm{L}\right)$ & $6.49(5.05-8.75)$ & $5.31(4.09-6.4)$ & $7.86(6.39-10.2)$ & $<0.001$ \\
\hline Neutrophil (\%) & $78.95(63.05-86.65)$ & $72.1(58.8-79.1)$ & $84(71.2-90.3)$ & 0.012 \\
\hline Neutrophil count $\left(\times 10^{9} / \mathrm{L}\right)$ & $4.81(2.14-6.86)$ & $3.83(2.01-4.97)$ & $6.53(2.96-8.91)$ & 0.024 \\
\hline Lymphocyte percentage (\%) & $9.15(4.5-15.55)$ & $14.75(9.9-23.6)$ & $5.9(3.8-9.6)$ & $<0.001$ \\
\hline Lymphocyte count $\left(\times 10^{9} / \mathrm{L}\right)$ & $0.65(0.39-1.07)$ & $0.71(0.57-1.1)$ & $0.53(0.34-0.84)$ & 0.109 \\
\hline Monocyte percentage (\%) & $6.45(0.36-11.7)$ & $7.35(0.39-11.8)$ & $1.09(0.32-11.1)$ & 0.414 \\
\hline Monocyte count $\left(\times 10^{9} / \mathrm{L}\right)$ & $0.63(0.38-104)$ & $0.57(0.39-0.83)$ & $0.74(0.33-122)$ & 0.467 \\
\hline Platelet count $\left(\times 10^{9} / \mathrm{L}\right)$ & $170(\mid 13.5-273)$ & $174.5(116-294)$ & $154.5(95-264)$ & 0.541 \\
\hline SOFA & $4(2-4)$ & $3(2-4)$ & $4(3-5)$ & 0.031 \\
\hline
\end{tabular}

immune cells. We tested the expression of PD-1 in CD4 $4^{+}$ and $\mathrm{CD}^{+} \mathrm{T}$ cells and found that the expression of PD-1 was only slightly increased in $\mathrm{CD}^{+} \mathrm{T}$ cells, but the difference was not statistically significant (Table 3 ). Whether Was there truly no difference in $\mathrm{T}$ cell apoptosis between the severe and critical groups? For further study, apoptosis of immune cells was determined by a FITC Annexin V Apoptosis Detection Kit I. Our findings showed that apoptosis was not different in lymphocytes, granulocytes, or monocytes between the severe and critical groups (Table 4). Identically, we found that lymphocyte levels were obviously decreased in the critical group compared with those in the severe group (14.82\% VS $30.82 \%$ ). To determine the reason for lymphocytic decline, we also

Table 2 Linear Correlation Analysis Between These Indicators and SOFA Score

\begin{tabular}{|l|c|c|}
\hline Indicators & $\mathbf{r}_{\mathbf{s}}$ & $\mathbf{P}$ \\
\hline White blood cell count $\left(\times 10^{9} / \mathrm{L}\right)$ & 0.4020 & 0.0015 \\
Neutrophil $(\%)$ & 0.2588 & 0.0478 \\
Neutrophil count $\left(\times 10^{9} / \mathrm{L}\right)$ & 0.2223 & 0.1248 \\
Lymphocyte percentage $(\%)$ & -0.4996 & 0.0000 \\
Lymphocyte count $\left(\times 10^{9} / \mathrm{L}\right)$ & -0.3346 & 0.0090 \\
Monocyte percentage $(\%)$ & -0.2489 & 0.0846 \\
Monocyte count $\left(\times 10^{9} / \mathrm{L}\right)$ & 0.0645 & 0.7260 \\
Platelet count $\left(\times 10^{9} / \mathrm{L}\right)$ & -0.3901 & 0.0021 \\
\hline
\end{tabular}

detected cell necrosis by the FITC Annexin V Apoptosis Detection Kit I and found that there were no differences in lymphocytes, granulocytes, or monocytes between the severe and critical groups (Table 4). Then, we detected the inflammatory cytokines IL-2, IL-4, IL-6, IL-10, TNF$\alpha$, and IFN- $\gamma$ and found that the levels of IL- 6 inflammatory were increased in the critical group compared with those in the severe group $(4.43 \mathrm{pg} / \mathrm{mL}$ VS $9.3 \mathrm{pg} / \mathrm{mL})$, but the levels of IL-2, IL-4, IL-10, TNF- $\alpha$, and IFN- $\gamma$ were no difference between the severe and critical groups (Table 5). There might be another reason for lymphocytic decline that we need to explore.

\section{The Expression of HLA-DR in T Cells and Monocytes}

HLA-DR, an indicator of sepsis prognosis, has been shown to be associated with the T cell subset Treg cells. Our findings showed that the expression of HLA-DR in T cells was not different between the severe and critical groups (36.28\% VS $27.44 \%$ ) and that there was no difference between the severe and critical groups regarding monocytes $(\mathrm{P}=0.41)$ (Table 6). Then, we detected the number of Treg cells and found that there was no difference between the severe and critical groups (Table 7). In addition to Treg cells, we also detected $\mathrm{CD}^{+}{ }^{+} \mathrm{T}$ cells, $\mathrm{CD} 8^{+} \mathrm{T}$ cells, B lymphocytes and NK lymphocytes in peripheral blood. Consistently, we obtained 
Table 3 The Characteristics of PD-I Expression of COVID-19 Patients

\begin{tabular}{|c|c|c|c|c|c|}
\hline Variables & Total $(n=28)$ & Severe Group $(n=\mid 2)$ & Critical Group $(n=16)$ & $\mathbf{t} / \chi^{2} / \mathbf{Z}$ & $\mathbf{P}$ \\
\hline Age (years) & $62.68 \pm 11.89$ & $64.42 \pm 11.39$ & $61.38 \pm 12.46$ & 0.663 & 0.513 \\
\hline Gender & & & & & 0.459 \\
\hline Female & $16(57.14)$ & $8(66.67)$ & $8(50.00)$ & & \\
\hline Male & $12(42.86)$ & $4(33.33)$ & $8(50.00)$ & & \\
\hline $\mathrm{CD}^{+} \mathrm{T}(\%)$ & $39.14 \pm 11.9$ & $46.23 \pm 8.89$ & $33.83 \pm 11.26$ & 3.144 & 0.004 \\
\hline $\mathrm{PDI}^{+} \mathrm{CD}^{+} \mathrm{T}(\%)$ & $28.05 \pm 9.35$ & $24.71 \pm 5.98$ & $30.56 \pm 10.74$ & -1.694 & 0.102 \\
\hline $\mathrm{CD}^{+} \mathrm{T}(\%)$ & $21.35(14.55-28.25)$ & $20.2(15.65-29)$ & $23.05(13.7-28.25)$ & -0.023 & 0.982 \\
\hline $\mathrm{PDI}^{+} \mathrm{CD} 8^{+} \mathrm{T}(\%)$ & $32.67 \pm 11.48$ & $33.05 \pm 13.39$ & $32.38 \pm 10.27$ & 0.15 & 0.882 \\
\hline
\end{tabular}

Note: $[\bar{x} \pm, M(I Q R), \mathrm{n}(\%)]$.

a negative result; the levels of those immune cells in peripheral blood did not change between the severe and critical groups (Table 8). Finally, we hypothesized that distribution might be the main reason for lymphocytic decline.

\section{Distribution of T Cells}

We additionally compared one male critical COVID-19 patient's T cell subsets (Figure 2) and cytokine levels (Table 9) in peripheral blood, BALF and pleural effusion.

Table 4 The Characteristics of Immune Cell Apoptosis in COVID-19 Patients

\begin{tabular}{|c|c|c|c|c|c|}
\hline Variables & Total $(n=14)$ & Severe Group (n=5) & $\begin{array}{c}\text { Critical Group } \\
\qquad(n=9)\end{array}$ & $\mathbf{t} / \chi^{2} / \mathbf{Z}$ & $P$ \\
\hline Age (years) & $61.79 \pm 7.84$ & $61.2 \pm 7.19$ & $62.11 \pm 8.58$ & -0.201 & 0.844 \\
\hline $\begin{array}{c}\text { Gender } \\
\text { Female } \\
\text { Male }\end{array}$ & $\begin{array}{l}9(64.29) \\
5(35.7 I)\end{array}$ & $\begin{array}{l}4(80.00) \\
\mathrm{I}(20.00)\end{array}$ & $\begin{array}{l}5(55.56) \\
4(44.44)\end{array}$ & & 0.580 \\
\hline $\begin{array}{l}\text { Granulocyte } \\
\text { Granulocyte (\%) } \\
\text { Necrosis cells (\%) } \\
\text { The late apoptosis cells (\%) } \\
\text { The early apoptosis cells (\%) } \\
\text { Apoptosis cells (\%) } \\
\text { Live cells (\%) }\end{array}$ & $\begin{array}{c}56.53 \pm 14.67 \\
1.06 \pm 0.6 \\
0.58 \pm 0.22 \\
2.4 \pm 0.97 \\
2.98 \pm 1.14 \\
95.97 \pm 1.46\end{array}$ & $\begin{array}{c}34 \\
0.7 \\
0.79 \\
3.2 \\
3.99 \\
95.3\end{array}$ & $\begin{array}{c}60.28 \pm 11.83 \\
1.12 \pm 0.63 \\
0.55 \pm 0.22 \\
2.27 \pm 0.99 \\
2.82 \pm 1.16 \\
96.08 \pm 1.57\end{array}$ & & \\
\hline $\begin{array}{l}\text { Lymphocyte } \\
\qquad \text { lym (\%) } \\
\text { Necrosis cells (\%) } \\
\text { The late apoptosis cells (\%) } \\
\text { The early apoptosis cells (\%) } \\
\text { Apoptosis cells (\%) } \\
\text { Live cells (\%) }\end{array}$ & $\begin{array}{c}20.54 \pm \mid \mathrm{I} .03 \\
\mathrm{I} .08(0.76-\mid .38) \\
0.33(0.2-0.83) \\
0.9(0.72-2.06) \\
1.16(0.93-3.07) \\
97.45(94.3-98.1)\end{array}$ & $\begin{array}{c}30.82 \pm 9.65 \\
0.67(0.6-1.35) \\
0.35(0.18-0.83) \\
0.76(0.75-8.23) \\
1.04(0.94-9.06) \\
96.9(90.3-98.5)\end{array}$ & $\begin{array}{c}I 4.82 \pm 6.96 \\
\text { I.II(0.98-I.38) } \\
0.3(0.21-0.52) \\
0.97(0.72-2.02) \\
1.27(0.93-2.54) \\
97.9(96 . I-98)\end{array}$ & $\begin{array}{c}3.604 \\
-1.200 \\
0.000 \\
0.400 \\
0.3337 \\
0.000\end{array}$ & $\begin{array}{c}0.004 \\
0.230 \\
1.000 \\
0.689 \\
0.7386 \\
1.000\end{array}$ \\
\hline $\begin{array}{l}\text { Monocyte } \\
\text { Monocyte (\%) } \\
\text { Necrosis cells (\%) } \\
\text { The late apoptosis cells (\%) } \\
\text { The early apoptosis cells (\%) } \\
\text { Apoptosis cells (\%) } \\
\text { Live cells (\%) }\end{array}$ & $\begin{array}{c}5.05(3.2 I-6.52) \\
9.95 \pm 9.06 \\
1.18(0.91-2.31) \\
3.84 \pm 1.52 \\
5.51 \pm 2.58 \\
84.54 \pm 10.01\end{array}$ & $\begin{array}{c}6.26(4.14-6.62) \\
3.78 \pm 2.27 \\
0.91(0.56-1.16) \\
3.83 \pm 1.6 \\
5.10 \pm 2.29 \\
91.12 \pm 2.58\end{array}$ & $\begin{array}{c}3.83(3.2 \mid-6.32) \\
\mid 3.38 \pm 9.69 \\
1.25(|.04-2.3|) \\
3.84 \pm 1.57 \\
5.74 \pm 2.84 \\
80.89 \pm 10.84\end{array}$ & $\begin{array}{c}0.801 \\
-2.148 \\
-1.067 \\
-0.018 \\
-0.43 \\
2.043\end{array}$ & $\begin{array}{c}0.423 \\
0.053 \\
0.286 \\
0.986 \\
0.6768 \\
0.064\end{array}$ \\
\hline
\end{tabular}

Note: $[\bar{x} \pm, M(I Q R), n(\%)]$. 
Table 5 Characteristics of Cytokines in COVID-19 Patients

\begin{tabular}{|c|c|c|c|c|c|}
\hline Variables & Total $(n=27)$ & Severe $(n=10)$ & Critical $(n=17)$ & $\mathbf{t} / \mathbf{Z} / \chi^{2}$ & $P$ \\
\hline Age(years) & $64.74 \pm 11.45$ & $62.9 \pm 10.58$ & $65.82 \pm 12.11$ & -0.63 & 0.5322 \\
\hline Gender & & & & & 0.6831 \\
\hline Female & $9(33.33)$ & $4(40.00)$ & $5(29.4 I)$ & & \\
\hline Male & $18(66.67)$ & $6(60.00)$ & $12(70.59)$ & & \\
\hline IL-2 (pg/mL) & $1.04 \pm 0.39$ & $1.14 \pm 0.4 \mathrm{I}$ & $0.98 \pm 0.38$ & 1.05 & 0.3054 \\
\hline IL-4 (pg/mL) & $1.34 \pm 0.59$ & $1.47 \pm 0.65$ & $1.27 \pm 0.57$ & 0.82 & 0.4214 \\
\hline IL-6 (pg/mL) & $6.11(4.17-15.56)$ & $4.43(2.55-7.15)$ & $9.3(5.2-30.98)$ & -2.2845 & 0.0223 \\
\hline IL-I0 (pg/mL) & $4.44(2.6-7.14)$ & $3.68(3.07-4.5)$ & $4.9(2.53-10.77)$ & -0.7782 & 0.4364 \\
\hline TNF (pg/mL) & $1.56 \pm 0.38$ & $1.7 \pm 0.41$ & $1.48 \pm 0.36$ & 1.52 & 0.1415 \\
\hline IFN- $\gamma(\mathrm{pg} / \mathrm{mL})$ & $1.01(0.85-1.14)$ & $1.05(0.85-1.17)$ & $\mathrm{I}(0.85-1.07)$ & 0.7035 & 0.4818 \\
\hline
\end{tabular}

Note: $[\bar{x} \pm, \mathrm{M}(\mathrm{IQR}), \mathrm{n}(\%)]$.

Table 6 The Characteristics of HLA-DR Expression in COVID-19 Patients

\begin{tabular}{|l|c|c|c|c|c|}
\hline Variables & Total (n=19) & $\begin{array}{c}\text { Severe } \\
\text { Group (n=4) }\end{array}$ & $\begin{array}{c}\text { Critical } \\
\text { Group } \\
(\mathbf{n = 1 5})\end{array}$ & $\mathbf{t} / \chi^{2}$ \\
\hline Age (years) & $63.74 \pm 8.55$ & $68.25 \pm 7.8$ & $62.53 \pm 8.58$ & 1.203 & 0.246 \\
\hline $\begin{array}{l}\text { Gender } \\
\text { Female } \\
\text { Male }\end{array}$ & $\begin{array}{c}10(52.63) \\
9(47.37)\end{array}$ & $\begin{array}{l}2(50.00) \\
2(50.00)\end{array}$ & $\begin{array}{l}8(53.33) \\
7(46.67)\end{array}$ & 1.000 \\
\hline T (\%) & $15.45 \pm 8.05$ & $17.09 \pm 6.45$ & $15.02 \pm 8.57$ & 0.446 & 0.661 \\
\hline HLA-DR ${ }^{+}(T)$ & $29.3 \pm 10.7$ & $36.28 \pm 12.18$ & $27.44 \pm 9.9$ & 1.52 & 0.147 \\
\hline Monocytes (\%) & $9.5 \pm 3.65$ & $10.39 \pm 3.13$ & $9.26 \pm 3.84$ & 0.539 & 0.597 \\
\hline HLA-DR ${ }^{+}$monocyte (\%) & $23.14 \pm 6.79$ & $20.58 \pm 2.77$ & $23.83 \pm 7.43$ & -0.845 & 0.410 \\
\hline
\end{tabular}

Note: $[\bar{x} \pm, \mathrm{n}(\%)]$.

Table 7 The Characteristics of CD4 ${ }^{+}$Treg in COVID-19 Patients

\begin{tabular}{|c|c|c|c|c|c|}
\hline Variables & Total $(n=40)$ & $\begin{array}{c}\text { Severe Group } \\
\quad(n=19)\end{array}$ & $\begin{array}{c}\text { Critical Group } \\
\qquad(n=2 I)\end{array}$ & $\chi^{2}$ & $P$ \\
\hline Age (years) & $63.48 \pm 11.15$ & $64.42 \pm 12.94$ & $62.62 \pm 9.48$ & 0.010 & 0.992 \\
\hline Gender & & & & 0.002 & 0.962 \\
\hline Female & $17(42.50)$ & $8(42.11)$ & $9(42.86)$ & & \\
\hline Male & $23(57.50)$ & II (57.89) & $12(57.14)$ & & \\
\hline CD4 ${ }^{+}$Treg (\%) & $9.49(8.24-11.45)$ & $9.43(8.27-11.09)$ & $9.77(8.2-11.6)$ & 0.000 & 1.000 \\
\hline
\end{tabular}

Note: $[\bar{x} \pm, \mathrm{n}(\%)]$.

There were no differences in the percentage of lymphocytes $(\mathrm{T} \%)$ or the percentage of $\mathrm{NK}$ cells $(\mathrm{NK} \%)$ in peripheral blood, BALF or pleural effusion. The lymphocyte absolute values (LYM\#) in peripheral blood, BALF and pleural effusion were 628, 156, and 299, respectively. T cell absolute values $(\mathrm{T} \#)$ were 479,116 , and 267 , respectively. $\mathrm{CD}^{+} \mathrm{T} \#$ 
Table 8 The Characteristics of T Cell Subset Expression in COVID-19 Patients

\begin{tabular}{|c|c|c|c|c|c|}
\hline Variables & Total $(n=20)$ & Severe Group $(n=5)$ & Critical Group $(n=15)$ & $\mathbf{t} / \chi^{2} / \mathbf{Z}$ & $P$ \\
\hline Age (years) & $62.90 \pm 9.4 I$ & $67.4 \pm 7.02$ & $61.4 \pm 9.83$ & 1.253 & 0.226 \\
\hline Gender & & & & & 1.000 \\
\hline Female & $10(50.00)$ & $3(60.00)$ & $7(46.67)$ & & \\
\hline Male & $10(50.00)$ & $2(40.00)$ & $8(53.33)$ & & \\
\hline $\mathrm{T}(\%)$ & $74.64 \pm 5.69$ & $76.73 \pm 4.44$ & $73.94 \pm 6.02$ & 0.949 & 0.355 \\
\hline $\mathrm{CD}^{+} / \mathrm{CD}^{+}(\%)$ & $47.42 \pm 6.77$ & $52.25 \pm 4.73$ & $45.82 \pm 6.69$ & 1.976 & 0.064 \\
\hline $\mathrm{CD}^{+} / \mathrm{CD}^{+}(\%)$ & $26.56 \pm 8.49$ & $23.95 \pm 5.88$ & $27.43 \pm 9.21$ & -0.785 & 0.443 \\
\hline $\mathrm{CDI} 9^{+}(\%)$ & $10.59 \pm 4.35$ & $9.08 \pm 3.01$ & $11.09 \pm 4.69$ & -0.891 & 0.385 \\
\hline $\mathrm{CDI}^{+} / \mathrm{CD}^{+}(\%)$ & $12.89(6.75-15.25)$ & $11.33(6-12.17)$ & $14.33(7.03-15.5)$ & -0.786 & 0.432 \\
\hline $\mathrm{H} / \mathrm{S}$ & $1.83(1.37-2.18)$ & $1.97(1.86-2.24)$ & $1.65(1.17-2.11)$ & 1.223 & 0.222 \\
\hline 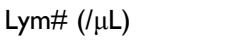 & $979.05 \pm 452.4$ & $1296 \pm 662.48$ & $873.4 \pm 323.3$ & 1.935 & 0.069 \\
\hline $\mathrm{T} \#(/ \mu \mathrm{L})$ & $732.6 \pm 345.22$ & $985.2 \pm 498.36$ & $648.4 \pm 245.76$ & 2.04 & 0.056 \\
\hline 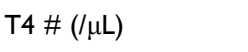 & $455.7 \pm 217.85$ & $638.4 \pm 287$ & $394.8 \pm 158.04$ & 2.429 & 0.026 \\
\hline 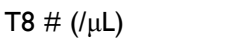 & $256.75 \pm 138.12$ & $299 \pm|77.4|$ & $242.67 \pm 126.68$ & 0.782 & 0.445 \\
\hline $\mathrm{B} \#(/ \mu \mathrm{L})$ & $100.85 \pm 55.5 \mid$ & $115.4 \pm 61.74$ & $96 \pm 54.7$ & 0.667 & 0.513 \\
\hline 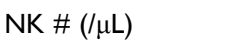 & || $6.95 \pm 80.9 \mid$ & $|50.6 \pm||5.0|$ & $105.73 \pm 67.58$ & 1.078 & 0.295 \\
\hline $\mathrm{CD}^{+} \mathrm{CD}^{+}(\%)$ & $2.34(I .8-2.8 I)$ & $2.64(2.14-2.83)$ & $2.31(1.69-2.78)$ & 0.873 & 0.383 \\
\hline $\mathrm{CD}^{+} \mathrm{CD}^{+} \#(/ \mu \mathrm{L})$ & $16(|1-2| .5)$ & $21(16-22)$ & $\mid 5(9-2 \mid)$ & 1.315 & 0.188 \\
\hline
\end{tabular}

Note: $[\bar{x} \pm, M(I Q R), \mathrm{n}(\%)]$.

were 321,41 , and 132 , respectively; $\mathrm{CD}^{+} \mathrm{T} \#$ were 155,70 , and 133, respectively; B cell absolute values (B\#) were 74, 9, and 7, respectively; NK cell absolute values (NK\#) were 42,13 , and 20, respectively; and $\mathrm{CD} 4^{+} \mathrm{CD}^{+} \mathrm{T}$ cell absolute values were 11,4 , and 24 , respectively.

For the cytokine levels in the three samples, we observed that IL-2 levels were highest in BALF (7.28 $\mathrm{pg} / \mathrm{mL})$, lowest in pleural effusion $(0.90 \mathrm{pg} / \mathrm{mL})$, and 1.84 in peripheral blood. IL-6 levels were remarkably increased in BALF and pleural effusion (600.38 and $2201.38 \mathrm{pg} / \mathrm{mL}$, respectively) compared with those in peripheral blood ( $42.84 \mathrm{pg} / \mathrm{mL})$. Moreover, IL-10 levels were higher in pleural effusion $(81.64 \mathrm{pg} / \mathrm{mL})$ than in peripheral blood $(26.36 \mathrm{pg} / \mathrm{mL})$ and BALF $(6.91 \mathrm{pg} / \mathrm{mL})$.

\section{Discussion}

This study analyzed severe and critical COVID-19 cases in Heilongjiang, China. This report is the first study to explore the mechanism of immunosuppression in critically ill COVID-19 patients. Recent studies have provided evidence for person-to-person transmission of SARSCoV-2. ${ }^{10,11}$ COVID-19 has become a global problem that needs to be solved immediately. To date, many clinical and epidemiological features of COVID-19 have been reported. $^{3,10-12}$ However, there is little knowledge of immunology in COVID-19. Our study is of great significance for further understanding COVID-19.

$\mathrm{T}$ cells play an important role in dealing with various disease-causing pathogens. ${ }^{4} \mathrm{~A}$ few studies have reported the decreased numbers and function of T cells in COVID19 patients, ${ }^{8,9}$ but the mechanism of the reduction in $\mathrm{T}$ cells is still unclear. Similarly, our study also found that the number of $\mathrm{T}$ cells was decreased in routine blood tests, particularly in critical patients. Then, we confirmed the reduction in $\mathrm{CD}^{+} \mathrm{T}$ cell levels by flow cytometry. A study verified $T$ cell exhaustion by measuring the exhaustion markers PD-1 and Tim- $3{ }^{9}$ but did not perform further research. Therefore, we hypothesized that $\mathrm{T}$ cell exhaustion might be due to apoptosis. Then, apoptosis and the expression of PD-1 in immune cells were detected. In 
A CD3-FITC/CD8-PE/CD45-PerCP/CD4-APC

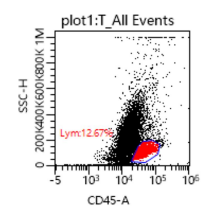

CD3-FITC/CD16+56-PE/CD45-PerCP/CD19-APC
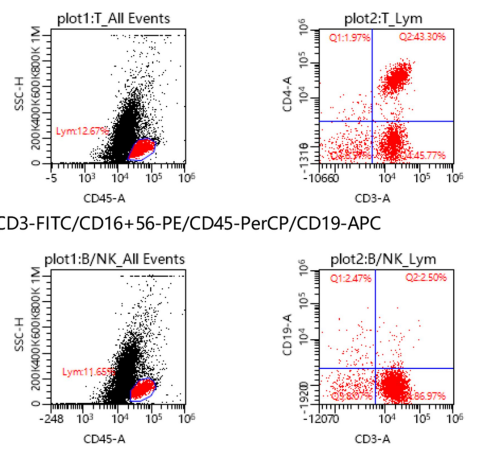

B

CD3-FITC/CD8-PE/CD45-PerCP/CD4-APC
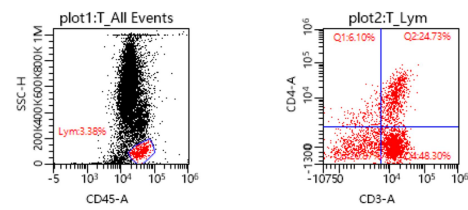

CD3-FITC/CD16+56-PE/CD45-PerCP/CD19-APC
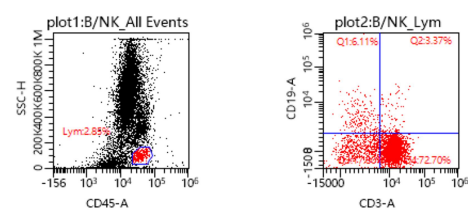

C
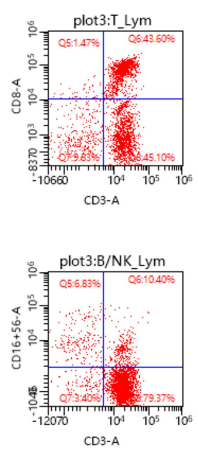

CD $-A$
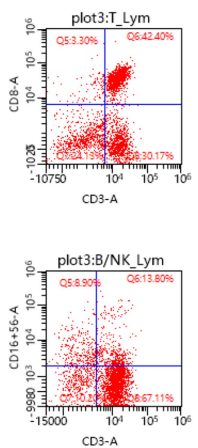

\begin{tabular}{lccc}
\hline \multirow{2}{*}{ T cell subset } & \multicolumn{3}{c}{ Patient } \\
\cline { 2 - 4 } & Peripheral blood & BALF & Fleural effusion \\
\hline
\end{tabular}

Age(years)

Gender Male

$\begin{array}{llll}\mathrm{T}(\%) & 76.28 & 74.55 & 89.27\end{array}$

$\begin{array}{llll}\mathrm{CD} 4+\mathrm{T}(\%) & 51.70 & 24.73 & 43.30\end{array}$

$\begin{array}{llll}\mathrm{CD} 8+\mathrm{T}(\%) & 25.00 & 42.40 & 43.60\end{array}$

$\begin{array}{llll}\mathrm{B}(\%) & 11.70 & 6.11 & 2.47\end{array}$

$\begin{array}{llll}\text { NK (\%) } & 6.53 & 8.90 & 6.83\end{array}$

$\begin{array}{llll}\mathrm{CD} 4+\mathrm{T} / \mathrm{CD} 8+\mathrm{T} & 2.07 & 0.58 & 0.99\end{array}$

Lym\#(/uL) $\quad 628 \quad 156 \quad 299$

$\begin{array}{llll}\text { TH( } / \text { uL }) & 479 & 116 & 267\end{array}$

$\begin{array}{llll}\mathrm{CD} 4+\mathrm{T} \#(/ \mathrm{uL}) & 321 & 41 & 132\end{array}$

$\begin{array}{llll}\mathrm{CD} 8+\mathrm{T} \#(/ \mathrm{uL}) & 155 & 70 & 133\end{array}$

$\begin{array}{llll}\mathrm{B} \#(/ \mathrm{uL}) & 74 & 9 & 7\end{array}$

NK\#(/uL) $\quad 42 \quad 13 \quad 20$

$\begin{array}{llll}\mathrm{CD} 4+\mathrm{CD} 8+(\%) & 2.36 & 3.01 & 8.79\end{array}$

$\begin{array}{llll}\mathrm{CD} 4+\mathrm{CD} 8+\#(/ \mathrm{uL}) & 11 & 4 & 24\end{array}$

Figure 2 The characteristics of T cell subset in peripheral blood, BALF and pleural effusion of COVID-19 patient. (A) The percentage of lymphocytes (T\%), B cells (B\%) or NK cells (NK\%) in pleural effusion. (B) The percentage of lymphocytes (T\%), B cells (B\%) or NK cells (NK\%) in BALF. (C) The characteristics of T cell subset in peripheral blood, BALF and pleural effusion.

fact, we confirmed that $\mathrm{CD}^{+} \mathrm{T}$ cell apoptosis and immune cell necrosis in critically ill patients was not more serious than that in severe COVID-19 patients by flow cytometry. They were not significantly different. In contrast, our study found that the expression of PD-1 was not increased significantly in $\mathrm{CD}^{+}$and $\mathrm{CD} 8^{+} \mathrm{T}$ cells in critical patients compared with those in severe patients. Our findings showed that apoptosis and cell necrosis levels were not different in lymphocytes, granulocytes, or monocytes

Table 9 The Characteristics of Cytokines in Peripheral Blood, BALF and Pleural Effusion of COVID-19 Patient

\begin{tabular}{|l|c|c|c|}
\hline \multirow{2}{*}{ Cytokines } & \multicolumn{3}{|c|}{ Patient } \\
\cline { 2 - 4 } & Peripheral Blood & BALF & Pleural Effusion \\
\hline $\mathrm{IL}-2(\mathrm{pg} / \mathrm{mL})$ & 1.84 & 7.28 & 0.90 \\
$\mathrm{IL}-4(\mathrm{pg} / \mathrm{mL})$ & 1.21 & 2.95 & 2.07 \\
$\mathrm{IL}-6(\mathrm{pg} / \mathrm{mL})$ & 42.84 & 600.38 & 2201.38 \\
$\mathrm{IL}-\mathrm{IO}(\mathrm{pg} / \mathrm{mL})$ & 26.36 & 6.91 & 81.64 \\
$\mathrm{TNF}-\alpha(\mathrm{pg} / \mathrm{mL})$ & 0.92 & 51.54 & 2.54 \\
$\mathrm{IFN}-\gamma(\mathrm{pg} / \mathrm{mL})$ & 1.62 & 16.99 & 2.68 \\
\hline
\end{tabular}

between the two groups. Therefore, we hypothesized that $\mathrm{T}$ cell exhaustion might be due to Treg cell proliferation. HLA-DR, an indicator of sepsis prognosis, has been reported to represent a natural $\mathrm{T}$ cell subset of $\mathrm{CD} 8^{+} \mathrm{HLA}-$ $\mathrm{DR}^{+}$Treg cells, which may play a suppressive effect. ${ }^{13} \mathrm{We}$ detected the expression of HLA-DR in T cells and monocytes and tested the level of Treg cells in peripheral blood. Unfortunately, we found that either Treg proliferation or the expression of HLA-DR was not significantly changed in critically ill COVID-19 patients compared with those in severe patients. It suggested that anti-PD-1 and HLA-DR immunotherapy may be useless in treatment. However, our data are different from the results of some current studies. Some studies have reported that the expression of PD- $1^{14}$ and TiM $3^{9}$ is increased in COVID-19 patients and associate with exhaustion of $\mathrm{T}$ Cells, while others have reported that the expression of HLA-DR is decreased in critically ill patients. ${ }^{15}$ Whatever the outcome, it could be due to that there are not enough patients enrolled, and too much uncertainty of the disease. 
Our findings indicated that $\mathrm{CD}^{+} \mathrm{T}$ cell apoptosis and Treg proliferation were not the reason for $\mathrm{T}$ cell exhaustion, at least not the main reason. Then, we analyzed one patient to detect the distribution of $\mathrm{T}$ cells. A surprising discovery was that a large number of $\mathrm{T}$ cells infiltrated the lungs in this critical patient, which might be the main reason for the lymphocytic decline in peripheral blood. Our findings were similar to those of Dr. Xu's autopsy report: inflammatory infiltration occurred in both lungs, especially by lymphocytes. ${ }^{16}$ However, we still need additional patients to detect the distribution of $\mathrm{T}$ cells.

When the virus invades the body, if the immune system is overactivated or uncontrolled, the infection induces an extreme immune response, releasing large amounts of cytokines that attack the host. This phenomenon is known as an "inflammatory storm." Similar to the case in SARS and Ebola, cytokine storms have become the main cause of death in COVID-19. ${ }^{17}$ Cytokine and chemokine levels are significantly increased in patients with severe infection and are associated with the severity of the disease, ${ }^{18}$ such as sepsis. In our study, we detected the levels of IL- 6 , IL-10, TNF- $\alpha$, and IFN- $\gamma$ in peripheral blood and found that the levels of IL- 6 were increased in the critical group compared with those in the severe group. However, according to our previous results, the number of $\mathrm{T}$ cells was reduced in the peripheral blood of critically ill patients. These two results seem to be contradictory, but this phenomenon may potentially be due to the activation of T cells. The function of activated $\mathrm{T}$ cells producing proinflammatory factors was enhanced in the peripheral blood of critically ill patients. Further study is needed to explore the function of inflammatory factor production in immune cells.

In addition to those findings, we detected cytokines from the alveolar lavage fluid and pleural effusion in one critically ill COVID-19 patient. Our findings showed that the level of IL- 6 was significantly increased compared with that in peripheral blood. Our findings indicated that the local extreme immune response in the lungs might be an important cause of death in critical patients. Recently, some studies reported that reducing the level of IL- 6 by sarilumab in peripheral blood might be helpful for the treatment of COVID-19 patients. ${ }^{19}$ According to our study, reducing the level of IL-6 in peripheral blood may not be useful for critically ill patients. In summary, our findings indicated that attenuating the concentration of IL- 6 or inhibiting the inflammatory response in the lungs might be a significant therapy for critically ill COVID-19 patients.

The limitations of this study were as follows: only 63 ill patients in Heilongjiang Province were enrolled. Heilongjiang Province is a cold region, and almost all patients have chronic bronchial and cardiovascular diseases, which may not represent the global situation for COVID-19. In addition, the results we obtained only described the function of $\mathrm{T}$ cells in severely and critically ill COVID-19 patients, and B lymphocytes, granulocytes, and monocytes have yet to be further explored. In addition, the cases we collected lacked continuous observation, and we did not follow up with the patients to obtain biological indicators of the recovery stage. Similarly, we did not collect the relevant data of mild COVID-19 cases and healthy people. There were too many studies that reported the levels of PD-1, HLADR and Treg in healthy people. The expressions of PD-1 in T cell and the levels of Treg both of severe and critical group were increased compared with healthy people, ${ }^{20-22}$ and the expressions of HLA-DR in $\mathrm{T}$ cell and monocytes were decreased compared with healthy people,${ }^{23-25}$ Our findings indicated that the severe immunosuppression in those COVID-19 patients. Finally, further COVID-19 studies at the molecular and gene levels are still needed.

\section{Conclusion}

There is severe immunosuppression in critically ill COVID-19 patients. Immune dysfunction may be attributed mainly to $T$ cell redistribution. Decreasing the number of $\mathrm{T}$ lymphocytes infiltrating the lung may be beneficial for the treatment of COVID-19.

\section{Abbreviations}

SARS-CoV-2, severe acute respiratory syndrome coronavirus 2; COVID, Corona Virus Disease; SOFA score, the Sequential Organ Failure Assessment score; PD-1, programmed cell death protein 1; HLA-DR, human leukocyte antigen-DR; Treg cells, regulatory $\mathrm{T}$ cells.

\section{Ethics}

The study was approved by the Ethics Committee of the First Affiliated Hospital of Harbin Medical University, Code number: kyk2020003, and was conducted in accordance with the Declaration of Helsinki.

\section{Acknowledgments}

This research supported by the National Natural Science Foundation of China (Nos.81571871, 81770276 and 81772045), Nn10 program of Harbin Medical University Cancer Hospital. This work was supported by Novel coronavirus pneumonia emergency treatment and diagnosis technology research project of Heilongjiang provincial science and Technology Department. 


\section{Author Contributions}

All authors made a significant contribution to the work reported, whether that is in the conception, study design, execution, acquisition of data, analysis and interpretation, or in all these areas; took part in drafting, revising or critically reviewing the article; gave final approval of the version to be published; have agreed on the journal to which the article has been submitted; and agree to be accountable for all aspects of the work.

\section{Disclosure}

The authors report no potential conflicts of interest.

\section{References}

1. Zhu N, Zhang D, Wang W, et al. A Novel Coronavirus from patients with pneumonia in China, 2019. $N$ Engl J Med. 2020;382 (8):727-733. doi:10.1056/NEJMoa2001017

2. Gralinski LE, Menachery VD. Return of the Coronavirus: 2019-nCoV. Viruses. 2020;12:135. doi:10.3390/v12020135

3. Huang C, Wang Y, Li X, et al. Clinical features of patients infected with 2019 novel coronavirus in Wuhan, China. Lancet (London, England). 2020;395:497-506. doi:10.1016/S0140-6736(20)30183-5

4. Zhu J, Paul WE. Peripheral CD4+ T-cell differentiation regulated by networks of cytokines and transcription factors. Immunol Rev. 2010;238:247-262. doi:10.1111/j.1600-065X.2010.00951.x

5. Bettelli E, Carrier Y, Gao W, et al. Reciprocal developmental pathways for the generation of pathogenic effector TH17 and regulatory T cells. Nature. 2006;441:235-238. doi:10.1038/nature04753

6. Durant L, Watford WT, Ramos HL, et al. Diverse targets of the transcription factor STAT3 contribute to T cell pathogenicity and homeostasis. Immunity. 2010;32:605-615. doi:10.1016/j. immuni.2010.05.003

7. Zhou L, Ivanov II, Spolski R, et al. IL-6 programs $\mathrm{T}(\mathrm{H})-17$ cell differentiation by promoting sequential engagement of the IL-21 and IL-23 pathways. Nat Immunol. 2007;8:967-974. doi:10.1038/ni1488

8. Chen G, Wu D, Guo W, et al. Clinical and immunological features of severe and moderate coronavirus disease 2019. J Clin Invest. 2020;130:2620-2629. doi:10.1172/JCI137244

9. Diao B, Wang C, Tan Y, et al. Reduction and functional exhaustion of $\mathrm{T}$ cells in patients with Coronavirus Disease 2019 (COVID-19). Front Immunol. 2020;11:827. doi:10.3389/fimmu.2020.00827

10. Li Q, Guan X, Wu P, et al. Early transmission dynamics in Wuhan, China, of Novel Coronavirus-infected pneumonia. $N$ Engl J Med. 2020;382:1199-1207. doi:10.1056/NEJMoa2001316

11. Chan JF, Yuan S, Kok KH, et al. A familial cluster of pneumonia associated with the 2019 novel coronavirus indicating person-toperson transmission: a study of a family cluster. Lancet (London, England). 2020;395:514-523. doi:10.1016/S0140-6736(20)30154-9
12. Chen N, Zhou M, Dong X, et al. Epidemiological and clinical characteristics of 99 cases of 2019 novel coronavirus pneumonia in Wuhan, China: a descriptive study. Lancet (London, England). 2020;395:507-513. doi:10.1016/S0140-6736(20)30211-7

13. Arruvito L, Payaslian F, Baz P, et al. Identification and clinical relevance of naturally occurring human CD8+HLA-DR+ regulatory $\mathrm{T}$ cells. J Immunol. 2014;193:4469-4476. doi:10.4049/ jimmunol.1401490

14. Moon C. Fighting COVID-19 exhausts T cells. Nat Rev Immunol. 2020;20:277. doi:10.1038/s41577-020-0304-7

15. Benlyamani I, Venet F, Coudereau R, Gossez M, Monneret G. Monocyte HLA-DR measurement by flow cytometry in COVID-19 patients: an interim review. Cytometry A. 2020;97(12):1217-1221. doi:10.1002/cyto.a.24249

16. Xu Z, Shi L, Wang Y, et al. Pathological findings of COVID-19 associated with acute respiratory distress syndrome. Lancet Respir Med. 2020;8:420-422. doi:10.1016/S2213-2600(20)30076-X

17. Younan $P$, Iampietro $M$, Nishida $A$, et al. Ebola virus binding to Tim-1 on T lymphocytes induces a cytokine storm. MBio. 2017;8. doi:10.1128/mBio.00845-17

18. La Gruta NL, Kedzierska K, Stambas J, Doherty PC. A question of self-preservation: immunopathology in influenza virus infection. Immunol Cell Biol. 2007;85:85-92. doi:10.1038/sj. icb. 7100026

19. Xu Y, Chen Y, Tang X. Guidelines for the diagnosis and treatment of COVID-19 by the National Health Commission (Trial Version 7). Global Health Med. 2020;2(2):66-72. doi:10.35772/ghm.2020.01015

20. Zhang C, Li F, Li J, Xu Y, Wang L, Zhang Y. Docetaxel down-regulates PD-1 expression via STAT3 in T lymphocytes. Clin Lung Cancer. 2018;19:e675-e683. doi:10.1016/j.cllc.2018.04.010

21. Xing YN, Zhang JY, Xu HM. The roles of serum CXCL16 in circulating Tregs and gastrointestinal stromal tumor cells. Onco Targets Ther. 2016;9:3939-3949. doi:10.2147/OTT.S105245

22. Wei T, Zhang J, Qin Y, et al. Increased expression of immunosuppressive molecules on intratumoral and circulating regulatory $\mathrm{T}$ cells in non-small-cell lung cancer patients. Am $J$ Cancer Res. 2015;5:2190-2201.

23. Papadopoulos P, Pistiki A, Theodorakopoulou M, et al. Immunoparalysis: clinical and immunological associations in SIRS and severe sepsis patients. Cytokine. 2017;92:83-92. doi:10.1016/j. cyto.2017.01.012

24. Yang HM, Yu Y, Chai JK, Hu S, Sheng ZY, Yao YM. Low HLA-DR expression on $\mathrm{CD} 14+$ monocytes of burn victims with sepsis, and the effect of carbachol in vitro. Burns. 2008;34:1158-1162. doi:10.1016/ j.burns.2008.01.026

25. Vester H, Dargatz P, Huber-Wagner S, Biberthaler $P$, van Griensven M. HLA-DR expression on monocytes is decreased in polytraumatized patients. Eur J Med Res. 2015;20:84. doi:10.1186/ s40001-015-0180-y
Journal of Inflammation Research

\section{Publish your work in this journal}

The Journal of Inflammation Research is an international, peerreviewed open-access journal that welcomes laboratory and clinical findings on the molecular basis, cell biology and pharmacology of inflammation including original research, reviews, symposium reports, hypothesis formation and commentaries on: acute/chronic inflammation; mediators of inflammation; cellular processes; molecular mechanisms; pharmacology and novel anti-inflammatory drugs; clinical conditions involving inflammation. The manuscript management system is completely online and includes a very quick and fair peerreview system. Visit http://www.dovepress.com/testimonials.php to read real quotes from published authors. 